Research Article

\title{
Effects of Coatings Containing Organic Ashes on the Corrosion Performance of Reinforcements
}

\author{
I. Sanri Karapınar (iD \\ Department of Civil Engineering, Maltepe University, Maltepe, 34857 Istanbul, Turkey \\ Correspondence should be addressed to I. Sanrı Karapınar; isanri@yahoo.com
}

Received 7 August 2019; Accepted 11 September 2019; Published 3 October 2019

Academic Editor: Jian Ji

Copyright (C) 2019 I. Sanrı Karapınar. This is an open access article distributed under the Creative Commons Attribution License, which permits unrestricted use, distribution, and reproduction in any medium, provided the original work is properly cited.

\begin{abstract}
The aim of this study is to investigate the corrosion performance of reinforcement steels coated with a coating containing wheat straw, sunflower stalk, and corn stalk ashes and moreover to discuss the effect of the coating on the concrete durability. By replacing calcite with different amounts of these organic ashes in the dye production, innovative corrosion inhibitive coating types were introduced. These coating types have been applied both on the reinforcement steels and concrete surface. In order to understand the effects of the coating types produced with these organic ashes, the steel bars coated with them containing $6 \%$ of the organic ashes as fine aggregate were embedded into concrete samples. The samples were cured both in tap water and $3.5 \% \mathrm{NaCl}$ solution for 180 days, and the mass losses of the steel bars were determined. Also, the inhibition efficiency of the coating was determined by using the galvanic cell method and accelerated corrosion tests. Furthermore, mass loss, compressive strength, abrasion resistance, freeze-thaw property, and capillary water permeability of the reinforced concrete samples with the produced coating were investigated. Test results showed that the minimum mass loss ratio in reinforcement was observed as $0.185 \%$ in samples coated with all three organic ash-added mixes. Also, for the same samples compressive strength loss was the lowest as $14 \%$. As a result, the durability of concrete and the corrosion resistance of steel bars improve with the addition of wheat straw, sunflower stalk, and corn stalk ashes into the coating and they could be used as environment-friendly corrosion inhibitors.
\end{abstract}

\section{Introduction}

The durability of concrete can be defined as the ability to maintain its strength and other properties during its service life without being negatively affected by its components and certain environmental conditions. Because of the external factors in different environmental conditions during its service life, concrete deteriorates and loses its properties. Then, it is evaluated as having completed its service life, and its usage would not be economically feasible anymore [1]. Permeability of water into concrete causes crack formation due to its expansion when it freezes, and this in turn causes corrosion when it reaches reinforcements. This process in addition to abrasion enhances the weakness in the durability of the reinforced concrete. Therefore, in order to reduce the permeability of concrete, the capillary porosity should be reduced as much as possible. Reducing water/cement ratio using less porous aggregate and mineral additives are some of the solutions to decrease the porosity of concrete. As a result, physical and chemical effects induce concrete cracking which increases the permeability. In addition to other durability problems, the increase in the permeability of concrete also initiates and accelerates the corrosion of reinforcement steel [2].

Corrosion is the material deterioration and material loss caused by the electrochemical effect of the environment $[3,4]$. Soft steels which are used as reinforcement in concrete are not resistant to corrosion in atmospheric and aqueous environments. However, the reinforcements in concrete resist corrosion for a long time. The electrical conductivity of concrete is rather low when it is dry. Hence, it acts as an electrolyte with high electrical resistance. Consequently, reinforcement steels in a normal concrete would not be exposed to corrosion [5]. Steel bars in concrete are exposed to corrosion in a similar way as in aqueous solutions. The iron in anode region is ionized. Iron ions are precipitated as 
iron hydroxide in an alkaline medium [6]. Since the $\mathrm{pH}$ level of concrete is high, there would be no hydrogen egression from the cathode. Cathode reaction can only proceed with oxygen reduction. Oxygen and water are needed for the corrosion of reinforcement steel. In other words, steel reinforcement would not be subjected to corrosion in dry concrete. The most severe corrosion is observed in concrete that is moistened and dried periodically [7].

For justifying the methodology to measure the performance of reinforced concrete, the bonding between concrete and steel is the most relevant property. The mass loss of reinforced concrete does not only involve a decrease in the cross-sectional area of reinforcements due to corrosion but the more important thing is that the bond between the steel and concrete is weakened by the corrosion taking place between the concrete and uncorroded section of the steel. Consequently, in order to evaluate the performance of reinforced concrete subjected to corrosion, changes in the bond properties have been investigated $[8,9]$. Studies have shown that when the bond between the reinforcement and surrounding concrete is decreased due to the mass loss of reinforcement caused by corrosion, the widths of the corrosion-induced cracks are increased. Therefore, in order to assess the impact of corrosion on the bond strength, the models based on the width of corrosion-induced cracks have been developed $[10,11]$.

Recently, it has been claimed that the use of mineral admixtures in concrete can reduce the corrosion of reinforcements. It has been confirmed in many studies that mineral admixtures, especially finely ground pumice and silica fume, hinder the corrosion of reinforcements [12-25]. There are many studies about the corrosion prevention of reinforcement steel. In the selection of corrosion prevention methods, the basic parameter is the atmospheric conditions. Although there are many methods to prevent corrosion, the most common way of increasing corrosion resistance is painting or coating the reinforcement [26-30]. In this respect, using organic coatings is one of the most effective applications for corrosion inhibition [31]. Due to environmental issues, there is a tendency to use new organic coating materials [32-35]. The purpose underlying all of these studies is to produce impermeable concrete and investigate the corrosion resistance of reinforcements with organic ashbased coating. However, there is still a need for further investigations on the development of novel environmentfriendly, organic coating materials to prevent reinforcement steel from corrosion.

In the literature, investigations about the performance of organic coatings containing agricultural wastes are very limited [36, 37]. Hence, in order to fulfill this need, the present study aims to propose the use of wheat straw, sunflower stalk, and corn stalk ashes in reinforcement coating. Towards this end, the corrosion performance of reinforcement steels with coating containing these agricultural wastes was investigated. The coating materials containing these organic ashes were produced in the laboratory. After coating the reinforcements with those materials, the corrosion rates were examined. Additionally, concrete samples were coated with the same materials, and their durability properties were investigated. The effect of coating materials on concrete-reinforcement adherence was also tested by adherence tests, and it was observed that there was no significant difference in the adherence properties. The results indicate that the agricultural wastes which are proposed as additives for the coating in the present study improve engineering properties and are appropriate to be used as novel anticorrosive coating material.

\section{Materials and Methods}

\subsection{Materials}

2.1.1. Wheat Straw. Wheat straw is the main body of wheat remaining after stalks and chaffs are removed. After the crops are cut, the root of the stem which remains in the field is called straw. Wheat straws which are abundant and burned by farmers in Turkey after the harvest time were collected appropriately. Then, they were burned in a container closed to the atmosphere to provide full combustion and cooled suddenly to obtain amorphous-structured ashes.

2.1.2. Sunflower Stalk. Sunflower is abundantly produced in Turkey. Sunflower stalk is the agricultural waste left in the field after harvesting sunflower. These sunflower stems are either burned or left in the field to rot like other agricultural wastes which is very harmful to the environment and ecosystem. Nowadays, increasing environmental concerns have led researchers to consider using this type of agricultural waste for food and nonfood purposes [38]. By transforming these materials into high-value products, their harms to the environment will be eliminated. Moreover, it will help the farmers to attain additional income by offering new jobs in rural areas.

2.1.3. Corn Stalk Ash. Corn is grown in almost every region in Turkey. In recent studies, by using corn stalks as agricultural wastes, insulation materials commensurate with the standards were produced [39]. With these studies, the people of the region benefit from the wastes, both in terms of mass production and employment, and also a contribution to the national economy is made. After the corn stalks were taken from the field, they were burned in an appropriate environment and temperature.

The chemical components of cement, wheat straw, sunflower stalk, and corn stalk ashes used in this study are given in Table 1.

2.1.4. Aggregate. The crushed stone aggregate used in this study is the same as that used in the production of the readymixed concrete in the city. The granulometric distribution of the aggregate used in the experiments is given in Figure 1.

The aggregates used in this study were subjected to Los Angeles abrasion test according to TS EN 1097-2 [40]. The abrasion amounts are $37 \%$ for $5-10 \mathrm{~mm}$ and $25 \%$ for $10-$ $32 \mathrm{~mm}$. Density and water absorption capacity of the aggregates were determined commensurating with TS EN 3526 [41]. These measurements were made using the pycnometer 
TABLE 1: Chemical components of the cement and organic ashes (\% by weight).

\begin{tabular}{lcccccccccc}
\hline Organic ashes and cement & $\mathrm{SiO}_{2}$ & $\mathrm{Al}_{2} \mathrm{O}_{3}$ & $\mathrm{Fe}_{2} \mathrm{O}_{3}$ & $\mathrm{CaO}$ & $\mathrm{MgO}$ & $\mathrm{K}_{2} \mathrm{O}$ & $\mathrm{Na}_{2} \mathrm{O}$ & $\mathrm{SO}_{3}$ & Loss on ignition & $\mathrm{Total}$ \\
\hline Cement & 24.7 & 6.5 & 3.8 & 51.1 & 1.6 & - & - & 2.9 & 7.3 & 99.9 \\
Wheat straw ash & 24.3 & 9.2 & 8.9 & 31.4 & 4.6 & 7.8 & 1.3 & 6.9 & 6.3 & 99.7 \\
Corn stalk ash & 37.4 & 6.1 & 5.3 & 23.1 & 6.0 & 7.1 & 2.5 & 4.5 & 7.4 & 99.4 \\
Sunflower stalk ash & 39.4 & 4.4 & 5.1 & 17.1 & 7.3 & 9.3 & 3.5 & 6.3 & 7.4 & 99.8 \\
\hline
\end{tabular}

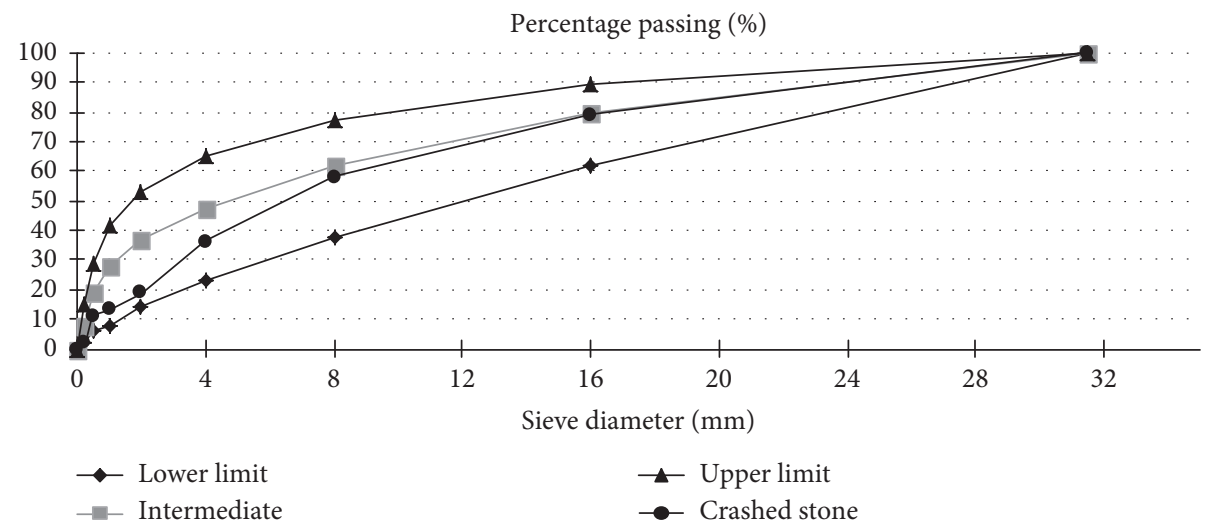

Figure 1: The granulometric distribution.

method for sand and Archimedes' scale method for coarse gravel on randomly collected samples. The density of the used crushed stone aggregate was found as $2.71 \mathrm{~kg} / \mathrm{dm}^{3}$.

2.1.5. Cement. In this study, CEM I 42,5R was used, and its chemical and physical properties are given in Tables 1 and 2, respectively.

2.1.6. Reinforcement Steel. Ribbed S420 grade reinforcement steel bars with $2 \times 10^{5} \mathrm{MPa}$ elasticity modulus, $14 \mathrm{~mm}$ diameter, and $60 \mathrm{~mm}$ length were used in the experiments.

2.1.7. Coating Components. Coating recipes and raw materials taken from a dye factory were used in the preparation of the coatings. The components used in the production of coatings were bioxide as thickener and viscosity enhancing material, calgon to resist water hardness, foam inhibitor as an antifoaming agent, ammonia as $\mathrm{pH}$ regulator, titanium as coloring pigment, and calcite and talc as fillers. The weights and ratios of the components of the coatings are given in Table 3.

\subsection{Method}

2.2.1. The Process of Obtaining Ashes. Wheat straws, sunflower stalks, and corn stalks were collected from the field and dried, and after being burned at $600^{\circ} \mathrm{C}$ for 1 hour, they were left to cool for 1 hour. Having been burnt at such a high temperature, the ashes were not homogeneous in size. Hence, they were ground in the crusher until the grain size was less than $1 \mathrm{~mm}$. Resulting ashes were sieved with a $1 \mathrm{~mm}$ diameter sieve.
TABle 2: Physical properties of the cement.

\begin{tabular}{lcccc}
\hline $\begin{array}{l}\text { Cement } \\
\text { type }\end{array}$ & $\begin{array}{c}\text { Density } \\
(\mathrm{kg} / \\
\left.\mathrm{cm}^{3}\right)\end{array}$ & $\begin{array}{c}\text { Specific } \\
\text { surface } \\
\left(\mathrm{cm}^{2} / \mathrm{g}\right)\end{array}$ & $\begin{array}{c}\text { Retained on } \\
\mu \text { sieve }(\%)\end{array}$ & $\begin{array}{c}\text { Retained on } \\
90 \mu \text { sieve } \\
(\%)\end{array}$ \\
\hline $\begin{array}{l}\text { CEM I } \\
42,5 \mathrm{R}\end{array}$ & 3.11 & 3230 & 0 & 2.8 \\
\hline
\end{tabular}

TABLE 3: The weights and ratios of the coating components.

\begin{tabular}{lcc}
\hline Material & Weight $(\mathrm{g})$ & Percent $(\%)$ \\
\hline Calcite (25 micron) & 9400 & 22.00 \\
Water & 4200 & 21.00 \\
Peva & 2800 & 14.00 \\
Titanium & 2600 & 13.00 \\
Talc & 400 & 2.00 \\
Aluminum silicate & 250 & 1.25 \\
Thinner & 100 & 0.50 \\
Natrason & 70 & 0.35 \\
Glycol & 50 & 0.25 \\
Ammonia & 40 & 0.20 \\
Calgon & 30 & 0.15 \\
Toxin & 30 & 0.15 \\
Wetting agent & 30 & 0.15 \\
Total & 20000 & 100 \\
\hline
\end{tabular}

2.2.2. Preparation of the Concrete Mixture. In this study, C25 concrete was used, and the mixtures were prepared according to TS EN 802 [42]. In the mixtures, water/cement ratio was taken as 0.5 . In the preparation of concrete samples, $6 \%, 3 \%$, and $2 \%$ of each kind of organic ash were used instead of fine aggregate for single, double, and triple combinations, respectively. Material amounts in the mixtures are presented in Table 4. 
TABLE 4: Component amounts in the concrete mixtures.

\begin{tabular}{lcc}
\hline Materials & $\begin{array}{c}\text { Reference sample } \\
(\mathrm{kg})\end{array}$ & $\begin{array}{c}\text { Samples with organic ash } \\
(\mathrm{kg})\end{array}$ \\
\hline Water & 215 & 220 \\
Cement & 400 & 400 \\
Organic ash & - & 40 \\
Sand & 660 & 620 \\
Coarse aggregate & 1100 & 1100 \\
\hline
\end{tabular}

2.2.3. Production of Coatings and Preparation of the Reinforcements. Recipes and raw materials used in the preparation of the coatings were taken from a paint factory. In mixing process, a concrete mixer with high mixing cycles (1000-1200 cycle/min) was used to obtain a homogeneous mixture. During mixing, a plastic container was also used so that the particles did not spill out of the concrete mixer. $9400 \mathrm{~g}$ of filler material, calcite, given in Table 3, was reduced to $5000 \mathrm{~g}$, and the remaining $4400 \mathrm{~g}$ was set to be used as given in Table 5. Ribbed S420 grade reinforcing steels were cut and painted with these produced coatings for the experiments. Throughout this work, samples with reinforcements having no coating materials were named as reference samples and designated as $\mathrm{R}$. The other reinforcements coated with the mixes containing wheat straw, sunflower stalk, and corn stalk ashes were designated as W, $\mathrm{S}$, and $\mathrm{C}$, respectively.

2.2.4. Coating of the Reinforced Concrete Samples. Three samples were prepared for each combination and coated with the produced mixes. Before coating, samples were kept in tap water and $3.5 \% \mathrm{NaCl}$ solution for 180 days. This sample preparation procedure was repeated for each test carried out in the whole study.

For the preparation of the concrete samples, $100 \times 100 \times 100 \mathrm{~mm}$ cubic molds were greased and concrete was poured in them in 2 layers. Each layer was compacted by rodding 25 times and tapping the outside of the molds with a mallet. After $24 \mathrm{~h}$, the samples were demolded, coated with mixes, and labelled.

\section{Experimental Work}

\subsection{Corrosion Tests on the Coated Reinforcement Steels}

3.1.1. Mass Loss Test. 4 steel bars of which the initial weights were determined by an electronic precision balance were put in each of the three concrete samples of all series with W, S, and $\mathrm{C}$. Then, they were placed into concrete samples using a special cap. The cap was placed on the upper part of the molds, and the steel bars were placed in the holes at all corners of the concrete samples and embedded into the concrete with the help of a hammer. After removing the caps, the top surfaces of the concrete samples were levelled, and in order to specify the location of each bar, labels showing the numbers of the bars at the four corners of the samples were attached. After 24 hours, the concrete samples were demolded, and the numbers of the steel bars were written near each one.
TABLE 5: Organic ash amounts in coatings.

\begin{tabular}{lccc}
\hline \multirow{2}{*}{ Sample codes } & \multicolumn{3}{c}{ Additive in the coating (g) } \\
& Wheat straw ash & Sunflower stalk ash & $\begin{array}{c}\text { Corn stalk } \\
\text { ash }\end{array}$ \\
\hline R & - & - & - \\
W & 4400 & - & - \\
S & - & 4400 & - \\
C & - & - & 4400 \\
WS & 2200 & 2200 & - \\
WC & 2200 & - & 2200 \\
SC & - & 2200 & 2200 \\
WSC & 1467 & 1467 & 1467 \\
\hline
\end{tabular}

The reinforced concrete samples were kept in $3.5 \% \mathrm{NaCl}$ solution for 180 days, and at the end of this curing time, the reinforcements were removed from the concrete. For removing the reinforcements from the concrete samples, the samples were put in the compression testing machine to be crushed. Then, the steel bars were removed by further crushing and cleaning the concrete on them with a hammer. Removed bars were cleaned by applying mechanical, chemical, and heat processes. Steel bars that were found to have no residues on the outer surfaces were dried thoroughly and then weighed on the precision balance to record their final weights.

3.1.2. Galvanic Cell Method. The purpose of the galvanic cell method is to sort the corrosion values of the steel bars from big to small by forming a simple galvanic cell [43]. In this method, two pieces of metals are immersed in an electrolyte and get in contact with each other where an electron exchange takes place by the created electric current. The sample which starts to corrode loses electrons. Due to the differences in the internal structures of the two metals, a potential difference is established between them and one of the metals starts to behave like anode and the other like cathode. If a voltmeter is connected between these two metals, the potential difference is easily measured. To achieve the foregoing procedure, 10 reinforcement steel bars each having a diameter of $10 \mathrm{~mm}$ and a length of $100 \mathrm{~mm}$ were prepared. These reinforcements, except the reference sample, were coated with the produced mixes and left to dry for 24 hours. After the preparation of the steel bars, a $3.5 \% \mathrm{NaCl}$ solution was homogeneously mixed in a container to obtain an electrolyte liquid.

Two copper sheets were immersed in this electrolyte and connected to a voltmeter in such a way that one of them was the anode and the other, the cathode. The reference value 0 was read on the voltmeter due to the fact that two metals of the same type were used. The $\mathrm{NaCl}$ solution prepared as the electrolyte liquid was evenly divided into 8 separate plastic containers, and the steel bars were put into these containers. A copper sheet was placed next to each steel bar. Then, one end of the voltmeter was connected to the steel bar and the other to the copper sheet. The potential difference between the two metals was read and recorded. 
3.1.3. Accelerated Corrosion Test. Accelerated corrosion method was used to examine the corrosion performance of the reinforcement steel inside the concrete. By taking three samples from each series, totally 96 steel bars of $160 \mathrm{~mm}$ length and $10 \mathrm{~mm}$ diameter were cut, and they were coated with the mixes containing organic ashes except the reference steel bars. They were left to dry for 24 hours. Then, the $100 \times 100 \times 100 \mathrm{~mm}$ molds were greased, and the mixture was poured in 2 layers. Each layer was, then, compacted by rodding 25 times and tapping the outside of the mold with a mallet. The dried steel bars were placed in the middle of the concrete with $10 \mathrm{~mm}$ concrete cover left from the bottom of the concrete. After 24 hours, the samples were demolded and cured for 28 days leaving the reinforcements outside the water. For the experimental setup, a $3.5 \% \mathrm{NaCl}$ solution was homogeneously mixed and evenly distributed to plastic containers. Two copper sheets, $100 \mathrm{~mm}$ long and $20 \mathrm{~mm}$ wide, were placed in each container. These copper sheets were connected to each other by a copper cable and connected to the negative pole of the power supply with direct current capacity (opposite electrode). A steel bar embedded in the middle of the concrete samples was placed in each plastic container and connected to the positive pole of the power supply by connecting the steel bars inside the concrete samples to each other with a copper cable (running electrode). Thus, a circuit is formed in which the reinforcement steel bars are the anode, the copper sheets are the cathode, and $\mathrm{NaCl}$ solution is the electrolyte. 30 volts of constant voltage was applied to the system. During the day, by separating the direct current from the source 4 times, the flow rate of each experimental setup was recorded at each time. At the same time, the formation of corrosion and cracks in concrete were continuously checked, and the progress was recorded.

\subsection{Tests on the Coated Reinforced Concrete}

3.2.1. Mass Loss of Concrete Samples Immersed in $\mathrm{NaCl}$ Solution. The reinforced concrete samples were removed from the $\mathrm{NaCl}$ solution, and the coating on the outer surfaces was cleaned with water. Cleaned samples were left in the laboratory conditions for 24 hours, and then, put in an oven to dry until their weights became constant. Then, they were taken out of the oven and weighed, and their mass losses were determined one by one.

3.2.2. Compressive Strengths of Concrete Samples. The compressive strengths of the concrete samples cured both in tap water and $\mathrm{NaCl}$ solution were determined.

3.2.3. Abrasion Resistance of Concrete Samples. Abrasion resistances of 28-day samples were determined according to DIN 52108 [44] by Boehme method. In order to find the surface abrasion, $100 \times 100 \times 100 \mathrm{~mm}$ cubic samples were produced, and on the $28^{\text {th }}$ day, they were cut to obtain new samples with $71 \times 71 \times 71 \mathrm{~mm}$ dimensions.
3.2.4. Capillary Water Permeability of Concrete Samples. Capillary water permeability rates of 28-day samples were investigated according to TS 3455 [45]. The prepared concrete samples were cured for 28 days and then dried at $105^{\circ} \mathrm{C}$ until constant weight was obtained, and the moisture inside was completely removed. Then, the side surfaces of the samples were covered with a waterproof material to allow water to seep in through a confined area. The samples were placed on wooden wedges, and the water was filled up to $5 \mathrm{~mm}$ above the bottom of the samples. Throughout the experiment, this water level was kept unchanged. The samples were weighed for 24 hours at $0,5,10,20,30,60,180$, 360 , and 1440 minutes.

3.2.5. Freeze-Thaw Property. The freeze-thaw test was performed according to TSE CEN/TR 15177 [46], and mass losses were calculated. Additionally, after freezing and thawing, compressive strengths of the samples were determined.

3.2.6. Pull-Out Test. Pull-out test was performed to determine the effect of the coating on the adherence between concrete and reinforcement. Three steel bars from each combination series, totally 24 test samples with $280 \mathrm{~mm}$ length and $10 \mathrm{~mm}$ diameter were prepared. $200 \mathrm{~mm}$ length of each sample was left outside the concrete with an embedded length of $80 \mathrm{~mm}$. Each was coated with the mixes up to a greater length than $80 \mathrm{~mm}$ and left to dry for 24 hours. $100 \times 100 \times 100 \mathrm{~mm}$ molds were greased and then the mixture was poured in 2 layers. Each layer was compacted by rodding 25 times. The dried reinforcements were placed at the midpoint of the concrete by leaving a $20 \mathrm{~mm}$ concrete cover from the bottom. After 24 hours, the demolded concrete was cured for 28 days by leaving the reinforcements outside the water. In order to perform the test, a special cap was used in the pull-out test machine.

\section{Results and Discussion}

\subsection{Corrosion of the Reinforcement Steels}

4.1.1. Mass Loss Results. Mass losses of the reinforcement steel bars removed from the $3.5 \% \mathrm{NaCl}$ solution were measured by a precision balance, and the results are given in Figure 2.

In Figure 2, the mass losses in the reinforcements coated with organic ash-added mixes were found to be extremely low compared to the reference sample, R. It was found out that the most effective inhibitive coating material in the corrosion of the steel bars which were kept in the $\mathrm{NaCl}$ solution for 180 days was the mix containing wheat straw, sunflower stalk, and corn stalk ashes, all together, WSC. The corresponding mass loss ratio was $0.185 \%$. The least mass loss in the single additive cases was observed in group $\mathrm{S}$. The sample with the highest mass loss was the uncoated reference sample, $\mathrm{R}$, with a ratio of $1.679 \%$. This value is approximately nine times the mass loss obtained with the triple combination, WSC. These results show that these ashes can be 


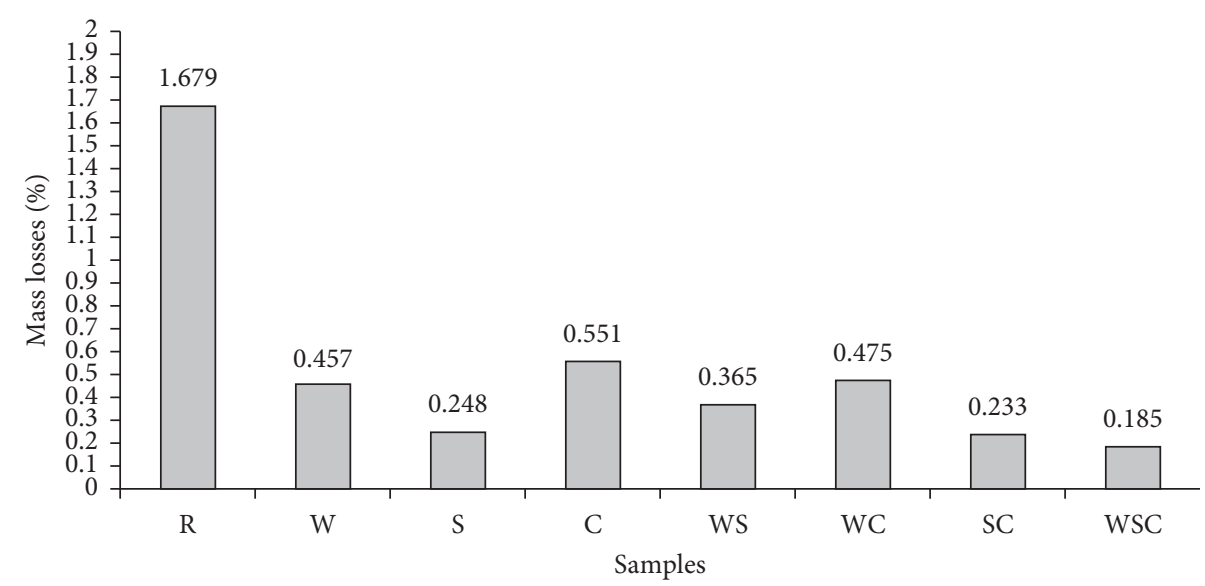

Figure 2: Mass losses of the reinforcement steels.

considered as additives for the coating mixes against reinforcement corrosion.

Since the ratio of silisium in the structure of $S$ is high, the mass losses of reinforcements were least with this additive. Coating the reinforcement steels with organic ash-added mixes to protect them against corrosion gave positive results. Corrosion was either delayed or prevented as the ashes contributed to the continuation of the alkaline environment formed in the concrete. Therefore, this coating system is suitable for the protection of the reinforcement steels from corrosion.

4.1.2. Results of the Galvanic Cell Method. The results of the galvanic cell method are given in Figure 3. In this test, where the steel bars behaved as anode and the copper sheet as cathode, the highest result was seen in the reference sample, R. The sample with the highest electron loss due to the electrolyte is the most destroyed, corroded sample. Consequently, as it is seen from the results, samples with the least potential difference value were the ones coated with WSC.

4.1.3. Results of the Accelerated Corrosion Test. The accelerated corrosion test was continued until all samples were exposed to corrosion and cracked. The experiment lasted 15 days, and a total of 50 measurements were made. The results of the accelerated corrosion tests are shown in Table 6. Each column represents the average of five measurements, and the last column shows the average of 50 measurements.

When the results are examined, among all the samples, the reference sample has generally drawn the highest current during the entire test, including the initial and final values. The highest current values in the reference samples are an indication of the highest amount of corrosion in them. Samples drawing the lowest current are those coated with the triple combination, where the current values were the least from the beginning till the end. Average of the current values for the reference samples was $0.186 \mathrm{~A}$ which was the highest and that for the WSC samples was the lowest with a value of $0.057 \mathrm{~A}$, which were roughly constant throughout the whole test. Following WSC, in drawing the least current, were, respectively, WS with an average of $0.058 \mathrm{~A}$ and $\mathrm{S}$ with an average of $0.068 \mathrm{~A}$.

Among the coated samples, the triple combination WSC, the double combination WS, and the single additive $S$ samples were the ones that drew the least current. As determined in previous studies, coating mixes with sunflower stalk ash were better insulations for water and electricity than the other ones $[38,39]$. Consequently, they show the best performance also in corrosion resistance. The triple mixtures have always performed very well in terms of protection due to their low electrical conductivity and tight coating structure. Samples coated with $\mathrm{S}$ and $\mathrm{C}$ gave better results compared to the ones coated with $\mathrm{W}$. On the other hand, the corrosion resistance of the samples coated with organic ash-added mixes was found to be much higher than the reference sample, $\mathrm{R}$. As a result, the study shows that these ashes may reduce the corrosion if they are used as additives to the cement.

\subsection{Results about the Coated Reinforced Concrete}

4.2.1. Mass Loss Results. The mass losses of the coated reinforced concrete samples removed from the $\mathrm{NaCl}$ solution at the end of the $180^{\text {th }}$ day are given in Figure 4 .

When the results are examined, it is seen that the coated samples were less affected by the saline medium than the reference samples. In the $180^{\text {th }}$ day samples, the maximum mass loss, $2.35 \%$ was observed in the reference samples and the minimum, $0.22 \%$, in WSC samples. This big difference can be explained by the thick coat inhibiting the salty water from entering the sample. Considering the importance of concrete impermeability in terms of durability, these test results are of great importance. Because of the coating, $\mathrm{NaCl}$ ions could not penetrate into the concrete easily and the corrosion of the reinforcement steel was delayed. Besides, because of the mineral admixtures, the concrete obtained was denser, and mass loss was prevented in concrete due to the effect of pozzolanic activity also.

4.2.2. Compressive Strength Results. Compressive strengths of the samples, kept in tap water and $\mathrm{NaCl}$ solution for 180 days, are given in Figures 5 and 6, respectively. 


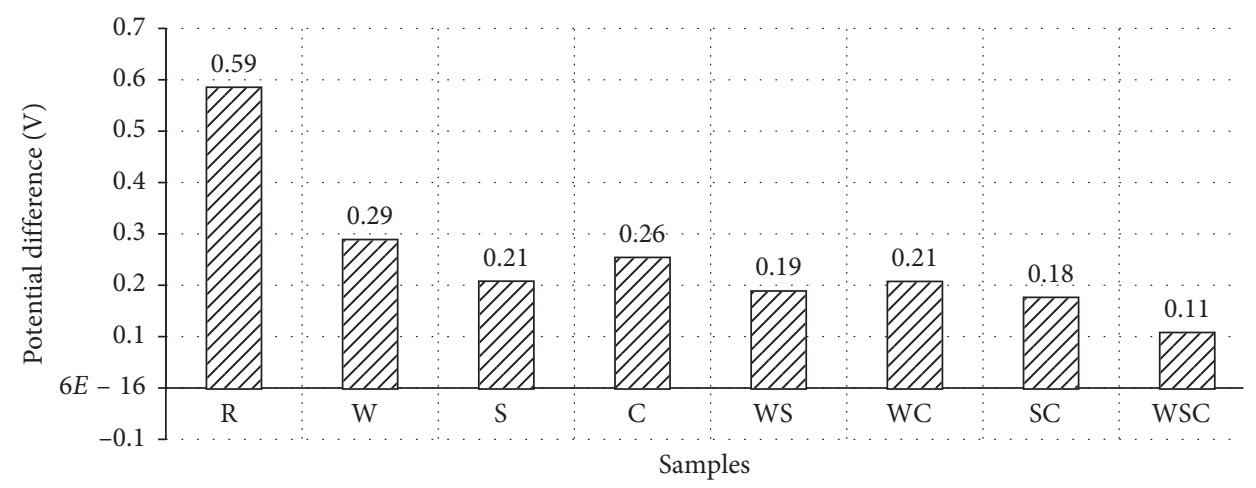

Figure 3: Potential difference values obtained from the galvanic cell method.

TABLE 6: Current measurements in the samples.

\begin{tabular}{lcccccccccccc}
\hline $\begin{array}{l}\text { Measurements } \\
\text { Samples }\end{array}$ & $1-5$ & $6-10$ & $11-15$ & $16-20$ & $21-25$ & $\begin{array}{c}26-30 \\
\text { Current values (A) }\end{array}$ & $\begin{array}{c}31-35 \\
\text { (A)-40 }\end{array}$ & 41-45 & $46-50$ & Average \\
\hline R & 0.074 & 0.085 & 0.129 & 0.157 & 0.226 & 0.213 & 0.257 & 0.23 & 0.245 & 0.248 & 0.186 \\
W & 0.063 & 0.069 & 0.078 & 0.086 & 0.094 & 0.121 & 0.22 & 0.204 & 0.197 & 0.185 & 0.132 \\
S & 0.038 & 0.045 & 0.052 & 0.063 & 0.074 & 0.084 & 0.095 & 0.127 & 0.01 & 0.093 & 0.068 \\
C & 0.048 & 0.053 & 0.068 & 0.077 & 0.088 & 0.093 & 0.123 & 0.138 & 0.012 & 0.012 & 0.071 \\
WS & 0.045 & 0.054 & 0.066 & 0.07 & 0.081 & 0.088 & 0.012 & 0.133 & 0.012 & 0.015 & 0.058 \\
WC & 0.058 & 0.063 & 0.078 & 0.087 & 0.093 & 0.099 & 0.128 & 0.142 & 0.022 & 0.018 & 0.07 \\
SC & 0.061 & 0.065 & 0.071 & 0.08 & 0.088 & 0.116 & 0.205 & 0.187 & 0.178 & 0.181 & 0.123 \\
WSC & 0.029 & 0.035 & 0.044 & 0.052 & 0.065 & 0.073 & 0.081 & 0.015 & 0.095 & 0.084 & 0.057 \\
\hline
\end{tabular}

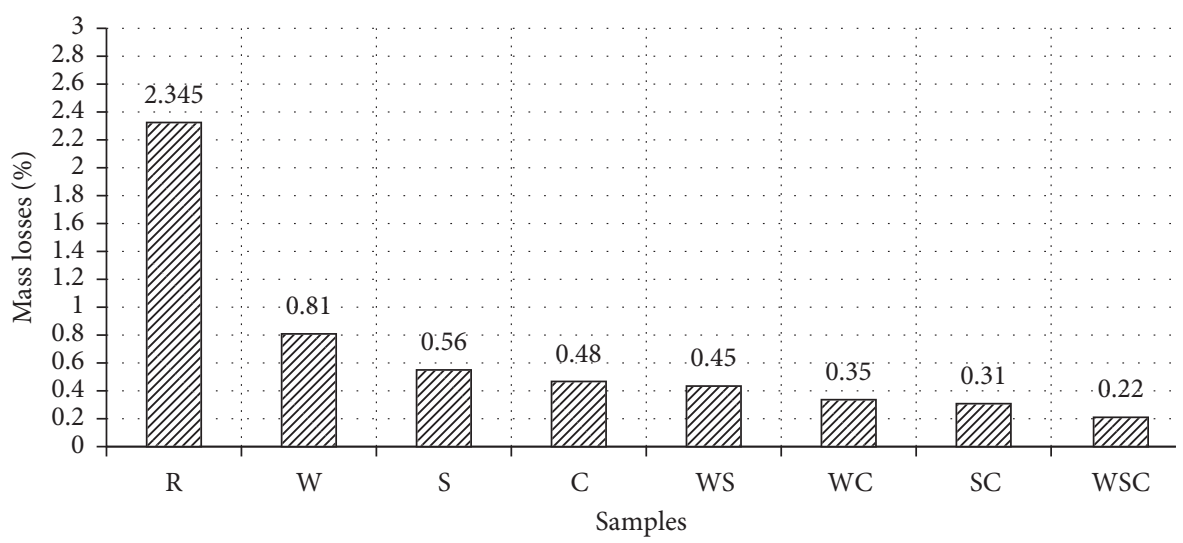

FIgURE 4: Mass losses of the reinforced concrete samples kept in $\mathrm{NaCl}$ solution.

As it is clear from the figures, the coated samples had higher compressive strengths compared to the uncoated ones. Among the samples kept in $\mathrm{NaCl}$ solution, the highest compressive strength loss was observed in $\mathrm{R}$ sample with $30 \%$ and the lowest in WSC sample with 14\%. According to the results achieved, salty water ions did not reach the coated concrete to cause structural damage. Hence, it is clear that the organic ash-added mixes improved the concrete durability.

4.2.3. Abrasion Resistance Results. Abrasion resistance values of the samples are given in Table 7. When the abrasion losses of the samples are examined, it is observed that the samples coated with organic ash-added mixes show more resistance against abrasion than the reference sample. The average abrasion rate of the coated concrete samples $\mathrm{W}, \mathrm{S}$, and $\mathrm{C}$ was $30 \%$ less than that of sample $\mathrm{R}$ and respective values for WS, WC and SC were $35 \%$ less than that of sample R. On the other hand, the abrasion rate of the coated concrete samples WSC was $40 \%$ less than that of sample R, revealing that the triple combination of the organic ashes has the highest resistance against abrasion.

4.2.4. Capillary Water Permeability Coefficients. Based on the capillary water permeability test results, the capillarity coefficients with respect to the water amount absorbed are given in Table 8 for each sample separately as capillary water permeability coefficient-time relationship. The capillary 


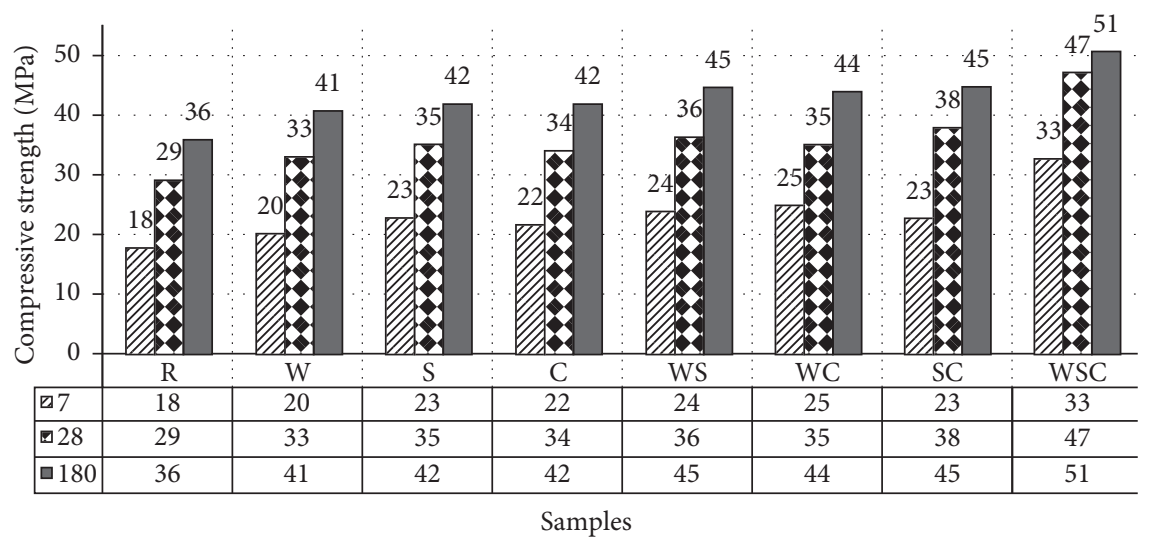

FIGURE 5: Compressive strengths of the samples kept in tap water.

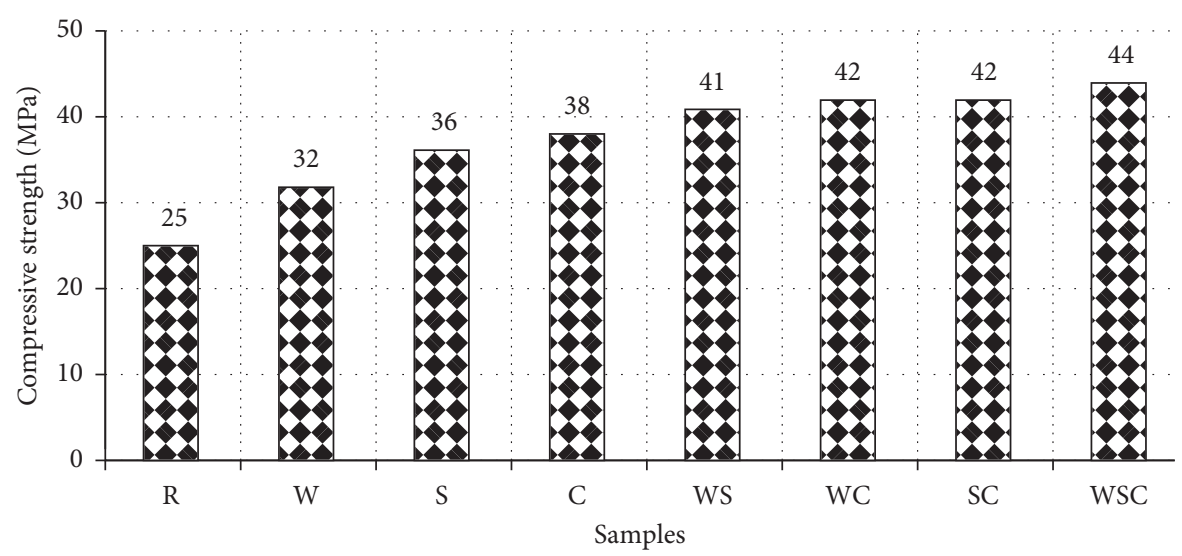

FIgURE 6: Compressive strengths of the samples kept in $\mathrm{NaCl}$ solution.

TABLE 7: Abrasion test results.

\begin{tabular}{lc}
\hline Samples & $\begin{array}{c}\text { Abrasion ratio } \\
\left(\mathrm{cm}^{3} / 50 \mathrm{~cm}^{2}\right)\end{array}$ \\
\hline $\mathrm{R}$ & 7.61 \\
$\mathrm{~W}$ & 5.65 \\
$\mathrm{~S}$ & 5.12 \\
$\mathrm{C}$ & 5.23 \\
Average rate for single additive case & 5.33 \\
WS & 4.89 \\
WC & 5.34 \\
SC & 4.67 \\
Average rate for double additive case & 4.94 \\
WSC & 4.56 \\
\hline
\end{tabular}

water permeability of the coated concrete samples was much lower than R. Since organic ash-added coatings form a new layer of the shield on the concrete surface, the capillary water absorption values decreased with time, and the samples absorbed less water depending on the organic ash combination.

When the capillary water permeability rates of the samples are examined, it is seen that the ones coated with organic ashadded mixes absorb less water than $\mathrm{R}$. The average capillary water permeability rate of the concrete samples coated with only one type of organic ash-added mixes was 35\%-70\% lower than that of sample $\mathrm{R}$, whereas for the concrete samples coated with two types of ash added mixes, the corresponding percentage range was $32 \%-72 \%$ and that for WSC was $22 \%-80 \%$. Hence, it is concluded that, especially, WSC is more resistant against the capillary water permeability. Since one of the main factors influencing the durability of concrete is attributed to its permeability, impermeability is very important in highly durable concrete production [47].

4.2.5. Freeze-Thaw Test Results. The mass and compressive strength losses of the 28-day concrete samples after the freeze-thaw tests are presented in Table 9. After freezing and thawing, the mass losses of the samples are different. There were not any observed cracking or spalling on the surfaces of the samples. Both mass and compressive strength losses in sample $\mathrm{R}$ were higher than those with organic ash-added coatings. The highest compressive strength loss was observed in sample R, whereas the lowest in sample WSC. Similarly, the minimum mass loss was also found in sample WSC. Organic ash-added coating prevented the formation of capillary cracks due to the formation of a new layer of the shield on the concrete surface. As a result of the coating of the samples, the water absorption rates of the samples were reduced, so that the compressive strength loss after the freeze-thaw test was also smaller than sample R. 
TABLE 8: Capillary water permeability coefficients $\left(\mathrm{cm} / \mathrm{s}^{1 / 2}\right) 10^{-6}$.

\begin{tabular}{lccccccccc}
\hline \multirow{2}{*}{ Samples } & \multicolumn{1}{c}{ Time (min) } \\
& 0 & 5 & 10 & 20 & 30 & 60 & 180 & 360 & 1440 \\
\hline $\mathrm{R}$ & 0 & 2.65 & 2.52 & 2.13 & 2.35 & 1.83 & 1.24 & 0.95 & 0.58 \\
$\mathrm{~W}$ & 0 & 0.86 & 1.61 & 1.76 & 1.48 & 1.38 & 0.69 & 0.48 & 0.41 \\
$\mathrm{~S}$ & 0 & 0.78 & 1.54 & 1.67 & 1.45 & 1.34 & 0.65 & 0.42 & 0.35 \\
$\mathrm{C}$ & 0 & 0.82 & 1.58 & 1.73 & 1.46 & 1.35 & 0.66 & 0.45 & 0.38 \\
Average rate for single additive case & 0 & 0.82 & 1.59 & 1.72 & 1.46 & 1.36 & 0.67 & 0.45 & 0.38 \\
WS & 0 & 0.72 & 1.51 & 1.62 & 1.40 & 1.31 & 0.62 & 0.39 & 0.33 \\
WC & 0 & 0.84 & 1.56 & 1.74 & 1.45 & 1.36 & 0.63 & 0.44 & 0.38 \\
SC & 0 & 0.71 & 1.50 & 1.58 & 1.39 & 1.28 & 0.58 & 0.37 & 0.31 \\
Average rate for double additive case & 0 & 0.76 & 1.53 & 1.65 & 1.42 & 1.32 & 0.61 & 0.40 & 0.34 \\
WSC & 0 & 0.55 & 1.34 & 1.44 & 1.35 & 1.25 & 0.54 & 0.34 & 0.30 \\
\hline
\end{tabular}

TABLE 9: Mass and compressive strength losses after freeze-thaw tests.

\begin{tabular}{lccc}
\hline Samples & Compressive strength (MPa) & Compressive strength loss (\%) & Mass loss (\%) \\
\hline R & 21.2 & 27 & 7 \\
W & 30.8 & 7 & 4.7 \\
S & 32.8 & 7 & 3.6 \\
C & 31.7 & 7 & 5.1 \\
Average values for single additive case & 31.6 & 5 & 4.1 \\
WS & 33.1 & 6 & 3.6 \\
WC & 35.9 & 4 & 3.8 \\
SC & 39.6 & 5 & 3.5 \\
Average values for double additive case & 36.2 & 3 & 3.6 \\
WSC & 39.8 & 2.7 \\
\hline
\end{tabular}

Table 10: Pull-out test results.

\begin{tabular}{lc}
\hline Samples & Tensile force $(\mathrm{N})$ \\
\hline R & 6185 \\
W & 6295 \\
S & 6305 \\
C & 6280 \\
WS & 6330 \\
WC & 6325 \\
SC & 6350 \\
WSC & 6380 \\
\hline
\end{tabular}

4.2.6. Pull-Out Test. There are studies focused on the effect of the levels of reinforcement corrosion on the bond degradation using the pull-out test $[48,49]$. Similarly, pull-out tests were carried out to evaluate the effects of corrosion on bond and bond-slip behaviour. Pull-out test results are given in Table 10. The very close tensile force values of the samples indicated that the coating on the steel bars did not significantly affect the adherence between concrete and steel.

\section{Conclusions}

In this study, protection of reinforcement against corrosion using a coating containing wheat straw, sunflower stalk, and corn stalk ashes was investigated, and the improvements in the corrosion performance were evaluated. The results obtained led to the following conclusions:

(i) Among all the samples immersed in $\mathrm{NaCl}$ solution for 180 days, the ones coated with WSC had the least mass loss, whereas sample $\mathrm{R}$ had the highest. (ii) According to the galvanic cell test, the minimum potential difference was found in sample WSC, whereas the maximum in sample $\mathrm{R}$.

(iii) Based on the accelerated corrosion test, the samples coated with $\mathrm{S}$ and $\mathrm{C}$ showed more corrosion resistance while the ones coated with $\mathrm{W}$ gave average values. However, even the corrosion resistance of these samples was much higher than $\mathrm{R}$.

(iv) Corrosion performances of the reinforcement steels which were coated with $\mathrm{S}$ were found to be the highest among the other ashes with high silisium ratio.

(v) In concrete samples coated with organic ash-added mixes, maximum mass loss was observed in $\mathrm{R}$ while the minimum in WSC.

(vi) The reference sample which was kept in the $\mathrm{NaCl}$ solution and tap water for 180 days had the highest compressive strength loss while WSC had the lowest.

(vii) Among the 28-day concrete samples, WSC had the lowest abrasion value while sample $\mathrm{R}$ had the highest.

(viii) WSC had the lowest permeability value among the 28-day concrete samples while sample $\mathrm{R}$ had the highest.

(ix) Since the samples were coated with organic ashes, the water absorption rates of these samples decreased. Therefore, the mass and compressive 
strength losses after freezing-thawing were much lower than that of sample R.

(x) According to the pull-out test results, the produced dye components did not have a negative effect on the adherence between the concrete and reinforcement. Anyhow, it was sample R that gave the lowest value.

Also, wheat straws, sunflower stalks, and corn stalks are easy to obtain because they are abundant in many parts of the world. In case of mass production, except the shipping cost, there is no big cost difference between the areas where the mixes for coating will be produced. From an economical point of view, since there is no difference in production and application with dyes, there is no financial burden in these phases. Moreover, it is possible to make an economic contribution by gaining new usage areas for these materials. Nowadays, many corrosion protection methods are used parallel to developing technology. However, these methods are both costly and laborious in terms of labor and applicability. Among these methods, the most convenient one in terms of production, application, and cost is the surface coating method.

In conclusion, the proposed coating containing the organic ashes obtained from the agricultural wastes are found to be effective coating materials to provide resistance against corrosion. The findings of this study indicate that these ashes can be used in composite coating production to prevent reinforcement corrosion and can be suggested as alternative, innovative, and environment-friendly corrosion inhibitors.

\section{Data Availability}

The data used to support the findings of this study are included within the article.

\section{Conflicts of Interest}

The author declares that there are no conflicts of interest regarding the publication of this paper.

\section{References}

[1] H. Binici and O. Aksogan, "Durability of concrete made with natural granular granite, silica sand and powders of waste marble and basalt as fine aggregate," Journal of Building Engineering, vol. 19, pp. 109-121, 2018.

[2] H. Binici, H. Zengin, G. Zengin, and F. Yasarer, "The use of pumice as a coating for the reinforcement of steel against corrosion and concrete abrasions," Corrosion Science, vol. 50, no. 8, pp. 2140-2148, 2008.

[3] I. Cil, "Corrosion measurement of rebars by electrical methods," Science and Engineering Journal, vol. 1, pp. 59-63, 2006, in Turkish.

[4] O. Keleştemur and B. Demirel, "Corrosion behaviour of reinforcing steel embedded in concrete produced with finely ground pumice and silica fume," Construction and Building Materials, vol. 24, no. 10, pp. 1898-1905, 2010.

[5] N. Yuzer, F. Akoz, and N. Ozhendekci, "Korozyon nedeni ile beton örtüyü çatlatan donatıdaki kesit kaybının belirlenmesi," Teknik Dergi, vol. 14, pp. 2923-2934, 2003, in Turkish.
[6] H. Binici, H. Zengin, G. Zengin, H. Kaplan, and F. Yucegok, "Resistance to sodium sulfate attack of plain and blended cement containing corncob ash and ground granulated blast furnace slag," Scientific Research and Essays, vol. 4, pp. 98-106, 2009.

[7] H. Binici, I. H. Cagatay, and H. Kaplan, "BOTAŞ petrol platformunda meydana gelen yapisal hasarlar," KSU Journal of Engineering Sciences, vol. 4, pp. 61-66, 2006, in Turkish.

[8] Q. Feng, A mechanics simulation of the influence of reinforcement corrosion on RC beam behaviour, Ph.D. thesis, The University of Adelaide, Adelaide, Australia, 2016.

[9] Q. Feng, P. Visintin, and D. J. Oehlers, "Deterioration of bond-slip due to corrosion of steel reinforcement in reinforced concrete," Magazine of Concrete Research, vol. 68, no. 15, pp. 768-781, 2015.

[10] H. Lin, Y. Zhao, P. Feng et al., "State-of-the-art review on the bond properties of corroded reinforcing steel bar," Construction and Building Materials, vol. 213, pp. 216-233, 2019.

[11] Q. Feng, P. Visintin, and D. J. Oehlers, "Effect of steel bar corrosion on flexural behaviour through bond," Proceedings of the Institution of Civil Engineers-Structures and Buildings, vol. 171, no. 5, pp. 380-394, 2018.

[12] H. Binici and O. Aksogan, "The use of ground blast furnace slag, chrome slag and corn stem ash mixture as a coating against corrosion," Construction and Building Materials, vol. 25, no. 11, pp. 4197-4201, 2011.

[13] K. M. A. Hossain, "Volcanic ash and pumice as cement additives: pozzolanic, alkali-silica reaction and autoclave expansion characteristics," Cement and Concrete Research, vol. 35, no. 6, pp. 1141-1144, 2005.

[14] B. Demirel and S. Yazicioglu, "Thermoelectric behavior of carbon fiber reinforced light weight concrete with mineral admixtures," New Carbon Materials, vol. 23, no. 1, pp. 21-24, 2008.

[15] K. M. A. Hossain, "Pumice based blended cement concretes exposed to marine environment: effects of mix composition and curing conditions," Cement and Concrete Composites, vol. 30, no. 2, pp. 97-105, 2008.

[16] K. M. A. Hossain, "Blended cement using volcanic ash and pumice," Cement and Concrete Research, vol. 33, no. 10, pp. 1601-1605, 2003.

[17] K. M. A. Hossain and M. Lachemi, "Performance of volcanic ash and pumice based blended cement concrete in mixed sulfate environment," Cement and Concrete Research, vol. 36, no. 6, pp. 1123-1133, 2006.

[18] T. Gonen and S. Yazicioglu, "The influence of mineral admixtures on the short and long-term performance of concrete," Building and Environment, vol. 42, no. 8, pp. 3080-3085, 2007.

[19] K. M. A. Hossain, "Properties of volcanic pumice based cement and lightweight concrete," Cement and Concrete Research, vol. 34, no. 2, pp. 283-291, 2004.

[20] J. Hou and D. D. L. Chung, "Effect of admixtures in concrete on the corrosion resistance of steel reinforced concrete," Corrosion Science, vol. 42, no. 9, pp. 1489-1507, 2000.

[21] D. D. L. Chung, "Corrosion control of steel-reinforced concrete," Journal of Materials Engineering and Performance, vol. 9, no. 5, pp. 585-588, 2000.

[22] O. Kelestemur and S. Yildız, "Effect of sodium chloride on corrosion of steel in normal concrete and produced by addition of silica fume," Firat University Science and Engineering Journal, vol. 17, no. 2, pp. 277-286, 2005, in Turkish.

[23] J. M. R. Dotto, A. G. de Abreu, D. C. C. Dal Molin, and I. L. Müller, "Influence of silica fume addition on concretes 
physical properties and on corrosion behaviour of reinforcement bars," Cement and Concrete Composites, vol. 26, no. 1, pp. 31-39, 2004.

[24] M. P. Kulakowski, F. M. Pereira, and D. C. C. D. Molin, "Carbonation-induced reinforcement corrosion in silica fume concrete," Construction and Building Materials, vol. 23, no. 3, pp. 1189-1195, 2009.

[25] O. Kayali and B. Zhu, "Corrosion performance of mediumstrength and silica fume high-strength reinforced concrete in a chloride solution," Cement and Concrete Composites, vol. 27, no. 1, pp. 117-124, 2005.

[26] M. P. Brent, "Investigation of field corrosion performance and bond/development length of galvanized reinforcing steel," A Report from Bridge Engineering Center, Iowa State University, Ames, Iowa, 2014.

[27] A. Weishaar, M. Carpenter, R. Loucks, A. Sakulich, and A. M. Peterson, "Evaluation of self-healing epoxy coatings for steel reinforcement," Construction and Building Materials, vol. 191, pp. 125-135, 2018.

[28] A. A. Almusalam, F. M. Khan, S. U. Dulaijan, and O. S. B. AlAmoudi, "Effectiveness of surface coatings in improving concrete durability," Cement and Concrete Composites, vol. 25, pp. 473-481, 2003.

[29] C. Gheorghe, "Studies and research work on the reinforcement steel and concrete surface corrosion protection methods," Urbanism, Arhitectură. Construcți, vol. 4, pp. 5-80, 2013.

[30] A. Elshami and H. A. Ali, "Using new coating materials for corrosion prevention of reinforced concrete," MATEC Web of Conferences, vol. 11, Article ID 01026, 2014.

[31] R. Selvaraj, M. Selvaraj, and S. V. K. Iyer, "Studies on the evaluation of the performance of organic coatings used for the prevention of corrosion of steel rebars in concrete structures," Progress in Organic Coatings, vol. 64, no. 4, pp. 454-459, 2009.

[32] N. M. Ahmed, M. G. Mohamed, M. R. Mabrouk, and A. A. Elshami, "Novel anticorrosive pigments based on waste material for corrosion protection of reinforced concrete steel," Construction and Building Materials, vol. 98, pp. 388-396, 2015.

[33] V. Jaskova and A. Kalendova, "Anticorrosive coatings containing modified phosphates," Progress in Organic Coatings, vol. 75, pp. 328-334, 2012.

[34] J. Sinko, "Challenges of chromate inhibitor pigments replacement in organic coatings," Progress in Organic Coatings, vol. 42, no. 3-4, pp. 267-282, 2001.

[35] N. M. Ahmed, M. G. Mohamed, R. H. Tammam, and M. R. Mabrouk, "Performance of coatings containing treated silica fume in the corrosion protection of reinforced concrete," Pigment \& Resin Technology, vol. 47, no. 4, pp. 350-359, 2018.

[36] M. G. Mohamed, N. M. Ahmed, and W. M. Abd El-Gawad, "Corrosion protection performance of reinforced steel coated with paints based on waste materials," Anti-Corrosion Methods and Materials, vol. 65, no. 4, pp. 368-374, 2018.

[37] H. Binici, F. Yucegok, O. Aksogan, and H. Kaplan, "Effect of corncob, wheat straw, and plane leaf ashes as mineral admixtures on concrete durability," Journal of Materials in Civil Engineering, vol. 20, no. 7, pp. 478-483, 2008.

[38] H. Binici, M. Eken, M. Dolaz, O. Aksogan, and M. Kara, “An environmentally friendly thermal insulation material from sunflower stalk, textile waste and stubble fibres," Construction and Building Materials, vol. 51, pp. 24-33, 2014.

[39] H. Binici, O. Aksogan, and C. Demirhan, "Mechanical, thermal and acoustical characterizations of an insulation composite made of bio-based materials," Sustainable Cities and Society, vol. 20, pp. 17-26, 2016.

[40] TS EN 1097-2, Test Method for Abrasion Resistance of Aggregates for Concrete, Turkish Standards Institute, Ankara, Turkey, 2000.

[41] TS EN 3526, Test Method for Specific Gravity and Water Absorbsion of Aggregates for Concrete, Turkish Standards Institute, Ankara, Turkey, 1981.

[42] TS EN 802, Design Concrete Mixes, Turkish Standards Institute, Ankara, Turkey, 2009.

[43] H. Binici, O. Aksogan, and M. Y. Durgun, "Corrosion of basaltic pumice, colemanite, barite and blast furnace slag coated rebars in concretes," Construction and Building Materials, vol. 37, pp. 629-637, 2012.

[44] DIN 52108, Testing of Inorganic Non-metallic Materials-Wear Test Using the Grinding Wheel According to Boehme-Grinding Wheel Method, DIN, Berlin, Germany, 2010.

[45] TS 3455, Test Method for Determining the Permeability Coefficient of Concrete, Turkish Standards Institute, Ankara, Turkey, 2013.

[46] TSE CEN/TR 15177, Testing the Freeze-Thaw Resistance of Concrete-Internal Structural Damage, Turkish Standards Institute, Ankara, Turkey, 2011.

[47] P. Chindaprasirt, P. Kanchanda, A. Sathonsaowaphak, and H. T. Cao, "Sulfate resistance of blended cements containing fly ash and rice husk ash," Construction and Building Materials, vol. 21, no. 6, pp. 1356-1361, 2007.

[48] C. Fang, K. Lundgren, M. Plos, and K. Gylltoft, "Bond behaviour of corroded reinforcing steel bars in concrete," Cement and Concrete Research, vol. 36, no. 10, pp. 1931-1938, 2006.

[49] F. Li and Y. Yuan, "Effects of corrosion on bond behavior between steel strand and concrete," Construction and Building Materials, vol. 38, pp. 413-422, 2013. 


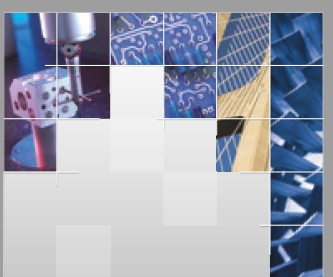

\section{Enfincering}
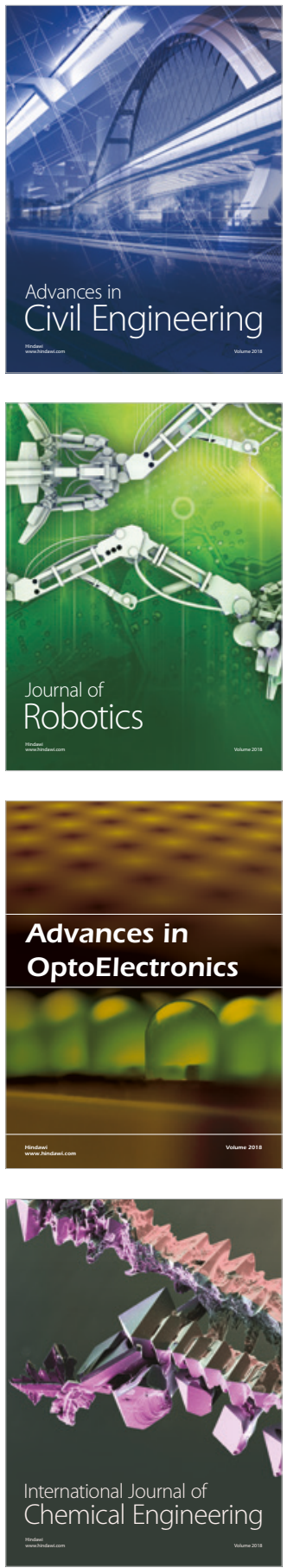

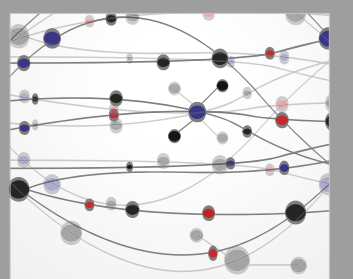

\section{Rotating \\ Machinery}

The Scientific World Journal

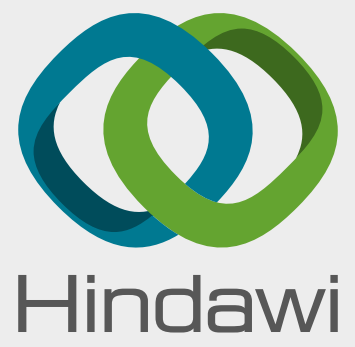

Submit your manuscripts at

www.hindawi.com
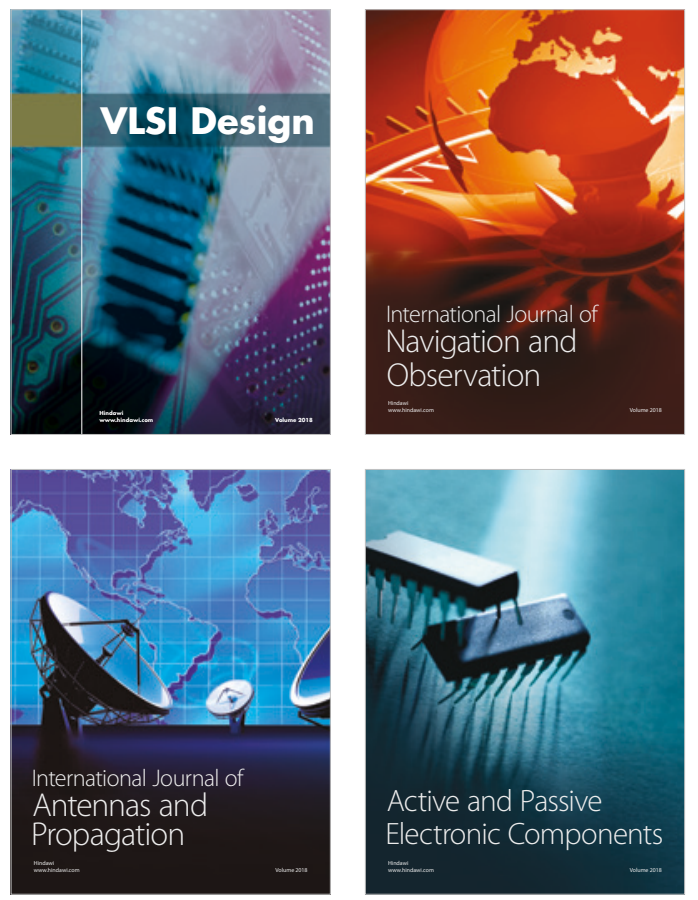
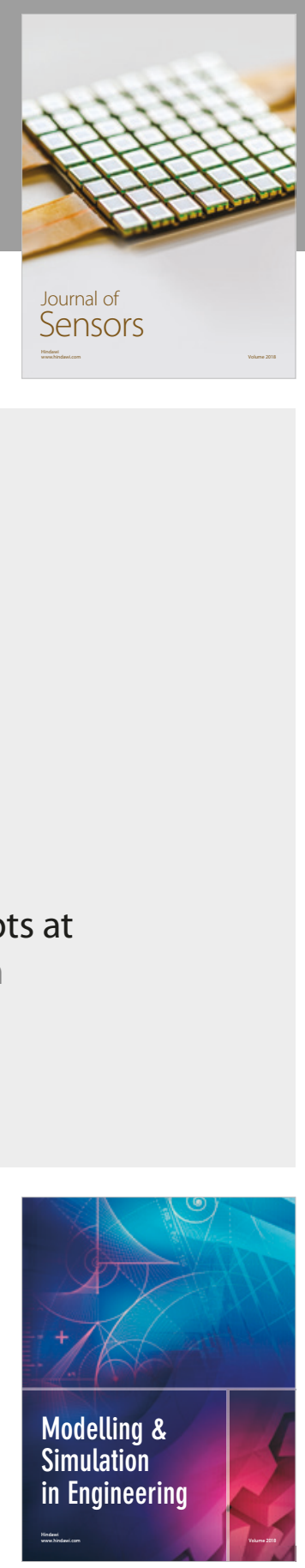

\section{Advances \\ Multimedia}
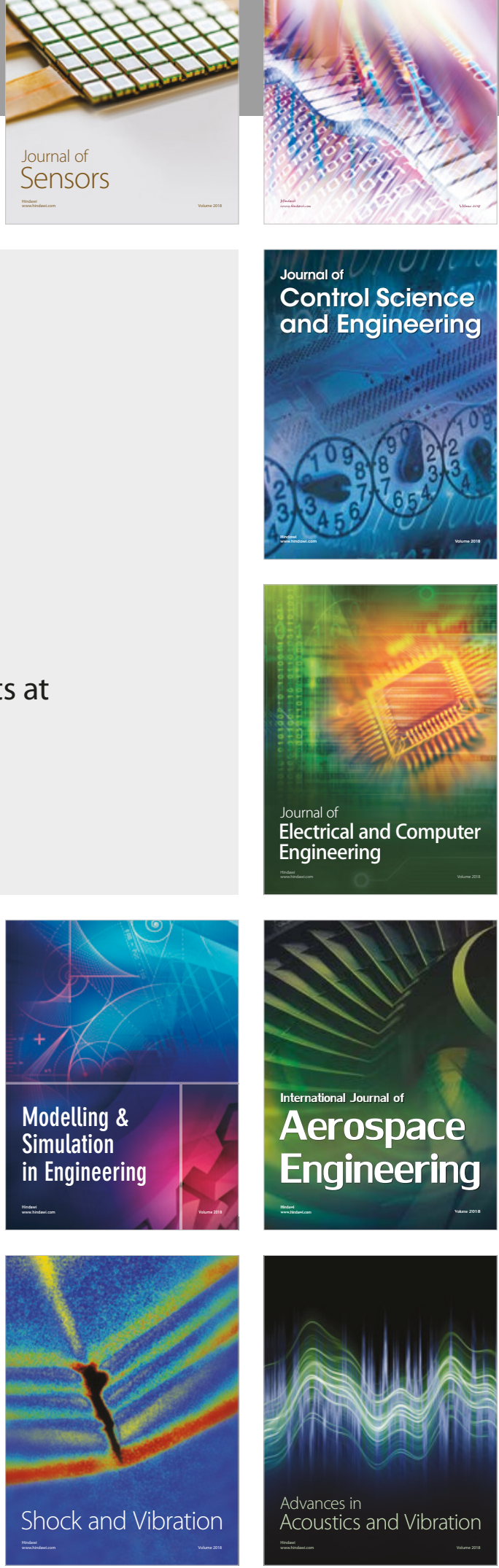